\title{
Genetic Resistance to Peronospora tabacina in Nicotiana langsdorffii, a South American Wild Tobacco
}

\author{
S. Zhang and D. Zaitlin
}

Kentucky Tobacco Research and Development Center, Cooper and University Drives, University of Kentucky, Lexington 40546-0236. Current address of first author: University of Florida/IFAS Tropical Research \& Education Center, 18905 SW 280 Street, Homestead 330313314.

Accepted for publication 14 December 2007.

\begin{abstract}
Zhang, S., and Zaitlin, D. 2008. Genetic resistance to Peronospora tabacina in Nicotiana langsdorffii, a South American wild tobacco. Phytopathology 98:519-528.

Several accessions of Nicotiana langsdorffii, a wild tobacco relative native to South America, express an incompatible interaction in response to infection by Peronospora tabacina, an oömycete that causes blue mold disease of tobacco (N. tabacum) and many other species of Nicotiana. In resistant accessions of $N$. langsdorffii, such as S-4-4, incompatibility takes the form of necrotic lesions that appear $48 \mathrm{~h}$ after pathogen inoculation, restricting pathogen growth, and suppressing subsequent asexual sporulation. Significantly elevated levels of salicylic acid and expression of a defense-related gene (HSR203J) were observed in S-4-4 leaves following blue mold infection. Genetic segregation analysis in $\mathrm{F}_{2}$ and modi-
\end{abstract}

ABSTRACT fied backcross populations showed that blue mold resistance is determined by a single dominant gene (NIRPT) present in S-4-4. Further characterization of this unique host-pathogen interaction has revealed that (i) necrotic lesion resistance is due to the hypersensitive response (HR), (ii) HR-mediated resistance is present in 7 of $10 \mathrm{~N}$. langsdorffii accessions examined, but not in closely related species, (iii) in some accessions of $N$. langsdorffii, resistance is expressed in cotyledon tissue and seedling leaves as well as in adult plants, and (iv) several resistant accessions including S-4-4 express an unregulated ("runaway") $\mathrm{HR}$ in response to $P$. tabacina infection.

Additional keywords: downy mildew, hypersensitive response, incompatibility, R-gene.
Blue mold, caused by the downy mildew pathogen Peronospora tabacina D. B. Adam (syn. P. hyoscyami de Bary), is an economically important disease of cultivated tobacco (Nicotiana tabacum L.). P. tabacina is an obligately biotrophic oömycete that can also infect many other species of Nicotiana $(18,28)$. During periods of cool and wet weather, $P$. tabacina can complete its lifecycle in less than 10 days, and the disease becomes polycyclic (29). This in turn results in near-continuous production of infective asexual sporangia (up to $10^{6} / \mathrm{cm}^{2}$ of infected leaf tissue), which can cause widespread blue mold epidemics. During such an epidemic in 1979 , more than $\$ 250$ million in losses were reported in the eastern United States and Canada $(29,44)$. Chemical treatment can effectively control blue mold on tobacco, however, resistance to metalaxyl, a systemic fungicide widely used against P. tabacina, has been reported in North American, Caribbean, and Central American isolates of the pathogen $(29,44,54)$. Utilization of host resistance to this devastating disease would be a preferred strategy of blue mold control in tobacco, given the economic cost and possible negative environmental effects of long-term fungicide application.

Host resistance to $P$. tabacina infection is low in $N$. tabacum (41), and most commercial cultivars are highly susceptible to blue mold disease. A number of Australian species of Nicotiana are resistant (or immune) to $P$. tabacina infection, and partial quantitative resistance has been transferred into cultivated tobacco from species such as $N$. debneyi Domin and N. goodspeedii Wheeler

Corresponding author: D. Zaitlin; E-mail address: dzait2@uky.edu

* The $\boldsymbol{e}$-Xtra logo stands for "electronic extra" and indicates that Figures 2, 3, and 4 appear in color online.

doi:10.1094/PHYTO-98-5-0519

(c) 2008 The American Phytopathological Society
(5-7,26). Two resistant cultivars, C-74 and Resistant Hicks, were released in the United States in 1958 and Australia in 1963, respectively, and both incorporated blue mold resistance from a resistant line of $N$. debneyi. Resistance from $N$. goodspeedii has also been exploited, and another two cultivars highly resistant to Australian strain APT-1 of P. tabacina, Sirone and Sirogo, were released in 1970 (52,53). In the United States, two partially resistant lines, NC-BMR-42 and NC-BMR-90, were developed in 1987 through in vitro anther culture and colchicine treatment (42). Few resistant cultivars, however, are available to tobacco growers (45). Natural sources of monogenic resistance to several other tobacco diseases have been identified in undomesticated species of Nicotiana and transferred into cultivated tobacco by breeding. Examples include the $N$ gene for resistance to TMV from $N$. glutinosa $(10,14), P h$ for resistance to black shank (Phytophthora parasitica var. nicotianae [Breda de Haan] Tucker) from N. plumbaginifolia Viv. (19), and monogenic dominant resistance to black root rot caused by Chalara elegans (synanamorph; Thielaviopsis basicola) from $N$. debneyi (24). A recent report by Milla et al. (32) identified 12 random amplified polymorphism DNA (RAPD) markers on a single tobacco linkage group linked in coupling phase to a major gene for blue mold resistance that originated in $N$. debneyi.

Previously, our laboratory reported the discovery and characterization of a recessive gene ( $r p t l)$ for resistance to $P$. tabacina in accession PI No. 555573 of the desert tobacco (N. obtusifolia M. Martens \& Galeotti) obtained from the United States Department of Agriculture (USDA) Tobacco Collection. N. obtusifolia is native to the deserts of North America, and further investigation showed that a similar or identical blue mold resistance phenotype (incompatibility) was expressed in one-third of progeny of plants collected in southern Arizona (13). Natural resistance to P. tabacina has not been identified in any species of Nicotiana origi- 
nating from outside of Australia or North America. We report here the discovery and initial characterization of genetic resistance to P. tabacina in N. langsdorffii Weinm. (Solanaceae, Nicotiana sect. Alatae), a species native to southeastern Brazil and adjacent parts of Argentina and Paraguay (11). The objectives of this research were to determine whether the resistance reaction observed in $N$. langsdorffii S-4-4 is due to the expression of genetic incompatibility via the hypersensitive response (HR), to define the mode of inheritance of the resistance phenotype in N. langsdorffii, and to determine the prevalence of the incompatible host-pathogen interaction within available accessions of the species.

\section{MATERIALS AND METHODS}

P. tabacina culture. P. tabacina isolate KY 79, originally collected from a tobacco field near Georgetown, KY, in 1979 (38), was used for inoculation in all experiments. The isolate was maintained by continuous serial propagation on 8- to 12-week-old plants of N. tabacum cv. KY14 as described (13).

$N$. langsdorffii plants and growth conditions. Seeds of $N$. langsdorffii accessions were obtained from the USDA Tobacco Collection, Institut fur Pflanzengenetik und Kulturpflanzenforschung (IPK) Gatersleben (Germany), and B\&T World Seeds (France) (Table 1). The original source of S-4-1 is unknown. Seeds were sown on moistened Pro-Mix BX (Premier Horticulture Inc., Quakertown, PA) and incubated in a plant growth chamber at a light intensity of $80 \mu \mathrm{mol} / \mathrm{m}^{2} / \mathrm{s}$ at $25^{\circ} \mathrm{C}$. Two to three weeks after germination, seedlings were transferred to $15-\mathrm{cm}$ diameter pots containing Pro-Mix, and maintained in growth chambers prior to use. Plants were fertilized every 1 to 2 weeks with $50 \mathrm{ml}$ of a solution containing $1.25 \mathrm{~g} / \mathrm{liter}$ Peters 20-20-20 (Grace-Sierra Horticultural Products, Milpitas, CA).

Plant inoculations and assays for reaction to $P$. tabacina infection. Plants of $N$. langsdorffii grown in Pro-Mix were tested for reaction to $P$. tabacina infection at the small seedling stage (2 to 4 weeks after germination) and near maturity (5 to 7 weeks after germination). Leaves of $N$. langsdorffii plants were inoculated with $P$. tabacina sporangia by drop inoculation. A water suspension containing $10^{5}$ sporangia/ml was used for all inoculations. Leaves were inoculated by applying $4 \mu \mathrm{l}$ of the sporangial suspension directly onto the adaxial surface of the leaf panels (6 to 8 sites/leaf, three leaves/plant). Inoculated plants were then placed in pre-moistened plastic tubs overnight before being moved onto shelves in a walk-in growth chamber $\left(21\right.$ to $22^{\circ} \mathrm{C}$, $12 \mathrm{~h}$ light/day, $50 \mu \mathrm{mol} / \mathrm{m}^{2} / \mathrm{s}$ ) specifically designed for blue mold containment. Plant reaction to blue mold infection was evaluated and recorded 1 week after inoculation.

In vitro assays for reaction of $N$. langsdorffii to $P$. tabacina infection. $N$. langsdorffii seeds were surface-disinfected with $70 \%$ ethanol for 2 min followed by $1 \%$ sodium hypochlorite for $30 \mathrm{~min}$, then rinsed in sterile distilled water three times. One seed was placed on $1 \mathrm{ml}$ of solidified $\mathrm{T}$ medium in each well of a 12well microtiter plate. $\mathrm{T}$ medium consists of $4.31 \mathrm{~g}$ of Murashige and Skoog salts per liter (Sigma Chemical Co, St. Louis, MO),

TABLE 1. Source of Nicotiana langsdorffii accessions used in this research

\begin{tabular}{ll}
\hline KTRDC accession no. & \multicolumn{1}{c}{ Seed source and original accession number } \\
\hline S-4-1 & Unknown; TO15 \\
S-4-2 & USDA Tobacco Collection; PI 42337 \\
S-4-3 & USDA Tobacco Collection; PI 555529 \\
S-4-4 & IPKz-Gatersleben; none (contaminant in NIC455) \\
S-4-5 & B\&T World Seeds; 32556 \\
S-4-6 & B\&T World Seeds; 85794 (cv. Cream Splash) \\
S-4-7 & IPK-Gatersleben; NIC22 \\
S-4-8 & IPK-Gatersleben; NIC41 \\
S-4-9 & IPK-Gatersleben; NIC404 \\
S-4-10 & IPK-Gatersleben; NIC528 \\
\hline
\end{tabular}

${ }^{\mathrm{z}}$ IPK: Institut fur Pflanzengenetik und Kulturpflanzenforschung (Germany).
$2 \mathrm{ml}$ of Gamborg's B5 vitamin stock per liter (5\% myo-inositol, $0.5 \%$ thiamin- $\mathrm{HCl}, 0.05 \%$ nicotinic acid, and $0.05 \%$ pyridoxine$\mathrm{HCl}), 3 \%$ sucrose, and $0.7 \%$ agar at $\mathrm{pH} 5.7$ to 5.9. Plates were placed in a growth chamber with $12 \mathrm{~h}$ light $(60 \mu \mathrm{mol} / \mathrm{m} / \mathrm{s})$ at 22 to $24^{\circ} \mathrm{C}$. Three to four weeks after sowing, seedlings were challenged with $P$. tabacina by applying a $1-\mu$ drop of the sporangial suspension $\left(10^{5} / \mathrm{ml}\right)$ onto a cotyledon or leaf. One to two weeks after pathogen inoculation, responses on cotyledons or leaves in individual $N$. langsdorffii accessions were evaluated and photographed by light microscopy.

Trypan staining and microscopic observations. Leaves of $N$. langsdorffii grown on T-Medium were sampled for trypan blue staining after drop inoculation with $P$. tabacina sporangia. Inoculated leaves of S-4-2 and S-4-4, along with $N$. tabacum KY14 (a highly susceptible cultivar of burley tobacco) were collected at 6 , $12,24,48$, and $96 \mathrm{~h}$ postinoculation (hpi). Accessions S-4-1, S-47, S-4-9, and S-4-10 were sampled at 48 and 96 hpi. Trypan blue staining was performed as described by Keogh et al. (25) with modifications. Briefly, inoculated leaves were fixed and completely cleared in Farmer's fluid (acetic acid/ethanol/chloroform $=1: 6: 3 \mathrm{vol} / \mathrm{vol}$ ) prior to staining with trypan blue. The cleared leaves were then incubated in a $0.03 \%$ (wt/vol) trypan blue solution (trypan blue in a 1:2 mixture of lactophenol/ethanol; for lactophenol, $10 \mathrm{~g}$ of phenol was added to a mixture of $10 \mathrm{ml}$ of lactic acid, $10 \mathrm{ml}$ of glycerol, and $10 \mathrm{ml}$ of distilled water) at $60^{\circ} \mathrm{C}$ in a water bath until they were completely stained, i.e., very intense blue or black color. The stained leaves were transferred to chloral hydrate solution $(2.5 \mathrm{~g} / \mathrm{ml})$ and de-stained at room temperature with gentle shaking until they were light blue. Tissues were then mounted in $50 \%$ glycerol for microscopic examination. Hyphae of $P$. tabacina stained dark blue in color, while plant tissues were light blue, making it possible to distinguish pathogen structures from the background of host plant cells under a light microscope.

Extraction and quantification of endogenous salicylic acid in $N$. langsdorffii accessions in response to $P$. tabacina infection. $N$. langsdorffii S-4-1, S-4-4, and [S-4-1 $\times$ S-4-4] $F_{1}$ plants were grown in $15-\mathrm{cm}$ diameter pots containing Pro-Mix BX for 7 weeks prior to use. Leaves were spray-inoculated to run-off with $P$. tabacina sporangia at a concentration of $10^{4} / \mathrm{ml}$ using a hand-held spray bottle. Treated plants were placed in premoistened containers overnight as described above. Leaves were sampled at $0,6,12,24,72$, and $120 \mathrm{hpi}$ and stored at $-80^{\circ} \mathrm{C}$ prior to salicylic acid (SA) extraction.

SA was extracted from leaves using the following technique: $1 \mathrm{~g}$ of leaf tissue was homogenized with liquid nitrogen and the ground tissue was mixed with $3.0 \mathrm{ml}$ of $90 \%$ methanol, sonicated for $20 \mathrm{~min}$, and centrifuged at 12,000 rpm for $20 \mathrm{~min}$. The pellet was extracted with $2 \mathrm{ml}$ of $100 \%$ methanol. The supernatant from two extractions was combined and dried under a nitrogen stream. The resulting residue was suspended in $2.5 \mathrm{ml}$ of $5 \%$ trichloroacetic acid (TCA) and centrifuged at $12,000 \times g$ for $10 \mathrm{~min}$. The supernatant was partitioned twice with $5 \mathrm{ml}$ of extraction solution (ethyl acetate/cyclopentane/isopropanol 50:50:1 by volume), and the top phase was collected and dried under a nitrogen stream. The residues were resuspended in $0.25 \mathrm{ml}$ of $20 \%$ methanol in $20 \mathrm{mM}$ sodium acetate buffer (pH 5.0). Solutions were filtered through a $0.22 \mu \mathrm{m}$ nylon membrane and stored at $-80^{\circ} \mathrm{C}$ prior to analysis.

Samples were analyzed by high performance liquid chromatography (HPLC) (Waters Corp., Milford, MA) using a Delta Pak C18 column (300 ̊, $5 \mu \mathrm{m}, 3.9 \times 150 \mathrm{~mm}$, NovaPack). The column was isocratically eluted with $20 \%$ methanol in $20 \mathrm{mM}$ sodium acetate buffer ( $\mathrm{pH} 5.0$ ) at a flow rate of $1.0 \mathrm{ml} / \mathrm{min}$. Absorbance at $280 \mathrm{~nm}$ was monitored with a tunable absorbance detector (Waters 486). Fluorescence emission at $370 \mathrm{~nm}$ (excitation $\lambda=295 \mathrm{~nm}$ ) was recorded with a scanning fluorescence detector (Waters 474). Twenty-microliter aliquots were injected 
into the column with a pressure of $21.1 \mathrm{~kg} / \mathrm{cm}^{2}\left(300 \mathrm{lb} / \mathrm{in}^{2}\right)$. Ultrapure water was used for dilution and preparation of all solutions. Quantification of SA for each experiment was performed three times.

Genetic segregation analysis of blue mold resistance in S-44. Flowers on a single $F_{1}$ plant of S-4-1 $\times$ S-4-4 were self-pollinated to produce $\mathrm{F}_{2}$ seed. Two modified backcross populations, BC1-1 and BC1-2, were developed by pollinating the S-4- $1 \times \mathrm{S}$ 4-4 $\mathrm{F}_{1}$ with $N$. forgetiana $\mathrm{S}-11-2$ and $N$. alata $\mathrm{S}-1-4$, respectively. Accessions of $N$. forgetiana and $N$. alata are highly susceptible to P. tabacina infection (S. Zhang and D. Zaitlin, unpublished data) and are interfertile with $N$. langsdorffii. In all, $168 \mathrm{~F}_{2}$ plants (in two experiments), $98 \mathrm{BC} 1-1$ plants (in one experiment), $80 \mathrm{BC} 1$ 2 plants (one experiment), and four plants of each of the parental lines and the $\mathrm{F}_{1}$ were drop inoculated with $P$. tabacina sporangia $\left(10^{5} / \mathrm{ml}\right)$ at 6 to 7 weeks of age. All plants in this experiment were grown under identical conditions in the greenhouse and were conditioned in the inoculation chamber for 3 to 5 days prior to inoculation. Inoculated plants were maintained as described above, and inoculated leaves were removed and placed in favorable conditions to induce $P$. tabacina sporulation as described above. Seven days after inoculation, plants were scored as follows: $1=$ necrosis (HR) without subsequent sporulation; $2=$ necrosis with light sporulation at the lesion margin; $3=$ chlorosis with a 1 to $2 \mathrm{~cm}$ zone of sporulation; and $4=$ chlorosis with a zone of sporulation larger than $2 \mathrm{~cm}$. Plant responses to $P$. tabacina infection were rated as either resistant (R; a score of 1$)$ or susceptible (S; scores of 2, 3, or 4). Symptoms of necrosis, chlorosis, and the relative levels of sporulation were recorded for each plant.

Effects of a metabolic inhibitor or antioxidant on development of the HR. A metabolic inhibitor and an antioxidant were tested for their ability to inhibit development of the HR on 7- to 8-week-old plants of $N$. langsdorffii accessions S-4-2 and S-4-4. Cobalt chloride $\left(\mathrm{CoCl}_{2}\right)$, a calcium channel blocker (3), and the sodium salt of salicylic acid (NaSA), an antioxidant (39), were selected for this experiment. Sporangial suspensions of $P$. tabacina were diluted in the inhibitor solutions to make mixtures containing $10^{5}$ sporangia/ml and 0.05 or $0.5 \mathrm{mM}$ inhibitors. Mixtures were infiltrated into leaf panels using a 1-ml syringe without needle until the spots reached $2-\mathrm{cm}$ in diameter. All five treatments with inhibitors or water were made on the same leaf (five inoculation sites per leaf, each treated with a different inhibitor concentration or water). Three fully developed leaves were used per plant, and each leaf was regarded as a replicate. Effects of the chemicals on HR development were quantified by measuring lesion diameter at 4 days postinoculation (dpi), and the data were transformed to the area of lesions. The plants then were placed in conditions conducive to pathogen sporulation. Additional controls consisted of uninoculated plants that were treated similarly with each inhibitor. The experiment was performed three times.

Analysis of transcript levels of $\mathrm{HSR203J}$ in plants by realtime polymerase chain reaction (PCR). Real-time PCR was performed to determine the relative transcript levels for the homolog of HSR203J after inoculation with P. tabacina. This gene is rapidly induced during incompatible host-pathogen interactions in tobacco $(35,50)$, and thus serves as a marker for systemic acquired resistance (SAR) and the HR (36). Leaf samples were collected from $N$. langsdorffii plants $(\approx 7$ weeks old) that had been previously sprayed with $P$. tabacina sporangia $\left(10^{4} / \mathrm{ml}\right)$ at 0 , $6,12,24,48,72$, and $120 \mathrm{hpi}$ and stored at $-80^{\circ} \mathrm{C}$. Total RNA was prepared using the RNeasy Plant Mini Kit (QIAGEN Inc., Valencia, CA) according to the manufacturer's instructions. RNA was treated with RNase-Free DNase I (Epicentre, Madison, WI) after isolation. Total RNA $(1 \mu \mathrm{g})$ was then used as a template for firststrand cDNA synthesis using M-MLV RT (Invitrogen, Carlsbad, CA). Real-time PCR was performed using the DNA Engine Opticon 2 System (MJ Research Inc., Waltham, MA). Quantita- tive real-time PCR $(20 \mu \mathrm{l})$ included $1 \mu \mathrm{l}$ of cDNA, $1 \mu \mathrm{l}$ of each primer $(5 \mu \mathrm{M}), 10 \mu \mathrm{l}$ of iTaq SYBR Green Supermix with ROX (Bio-Rad), and $7 \mu \mathrm{l}$ of water. The primers used (203B-1F: 5'CAATCATTGTCTCCGTCTTC-3', 203B-1R: 5'-GGTTGAAATCTGCGAAATC- $3^{\prime}$ ) directed amplification of a 150-bp product from the $N$. langsdorffii homolog of tobacco HSR203J. Quantitative real-time PCR was carried out using the following conditions: $94^{\circ} \mathrm{C}$ for $2 \mathrm{~min}$ and 34 cycles of $94^{\circ} \mathrm{C}$ for $30 \mathrm{~s}, 51^{\circ} \mathrm{C}$ for $30 \mathrm{~s}$, and $72^{\circ} \mathrm{C}$ for $40 \mathrm{~s}$, and finally $72^{\circ} \mathrm{C}$ for $5 \mathrm{~min}$. Alternatively, end-point reverse-transcriptase PCR was performed with cDNA, synthesized as described before, under the following conditions: $95^{\circ} \mathrm{C}$ for $2 \mathrm{~min}$ and 30 cycles of $94^{\circ} \mathrm{C}$ for $30 \mathrm{~s}, 51^{\circ} \mathrm{C}$ for $30 \mathrm{~s}$, and $72^{\circ} \mathrm{C}$ for $1 \mathrm{~min}$, and finally $72^{\circ} \mathrm{C}$ for $7 \mathrm{~min}$. PCR was performed prior to cDNA synthesis to verify that there was no genomic DNA contamination of the RNA samples. For the negative control, template RNA was not added to the reaction mixtures. The products of reverse transcriptase-PCR were visualized by electrophoresis on a $1.5 \%$ agarose gel. Expression of a 165-bp region of the tobacco alpha tubulin gene (GenBank accession no. AB052822) (primer 643; forward, 5'-ATGAGAGAGTGCATATCGAT-3', primer 644; reverse, 5'-TTCACTGAAGAAGGTGTTGAA-3': gift of I. B. Maiti) homolog was included to verify uniform sample loading. The DNA fragment $(150 \mathrm{bp})$ amplified with primers 203B-1F and 203B-1R from cDNA was cloned into the pGEM-T Easy vector (Promega Corporation, Madison, WI), and plasmid DNA containing the fragment was used as the standard control. Quantitative real-time PCR experiments were performed three times.

\section{RESULTS}

Reaction of $\boldsymbol{N}$. langsdorffii to $\boldsymbol{P}$. tabacina infection. Ten accessions of $N$. langsdorffii (Table 1) were examined for their response to $P$. tabacina infection on leaves of soil-grown adult plants, as well as on cotyledons and leaves of seedlings grown aseptically on artificial T-Medium. In general, accessions of $N$. langsdorffii varied by age and genotype in their individual responses to infection by $P$. tabacina (Table 2).

Adult plants. Seven of ten plant accessions tested displayed an incompatible interaction (HR), and three displayed a fully compatible interaction after leaf inoculation of adult plants with
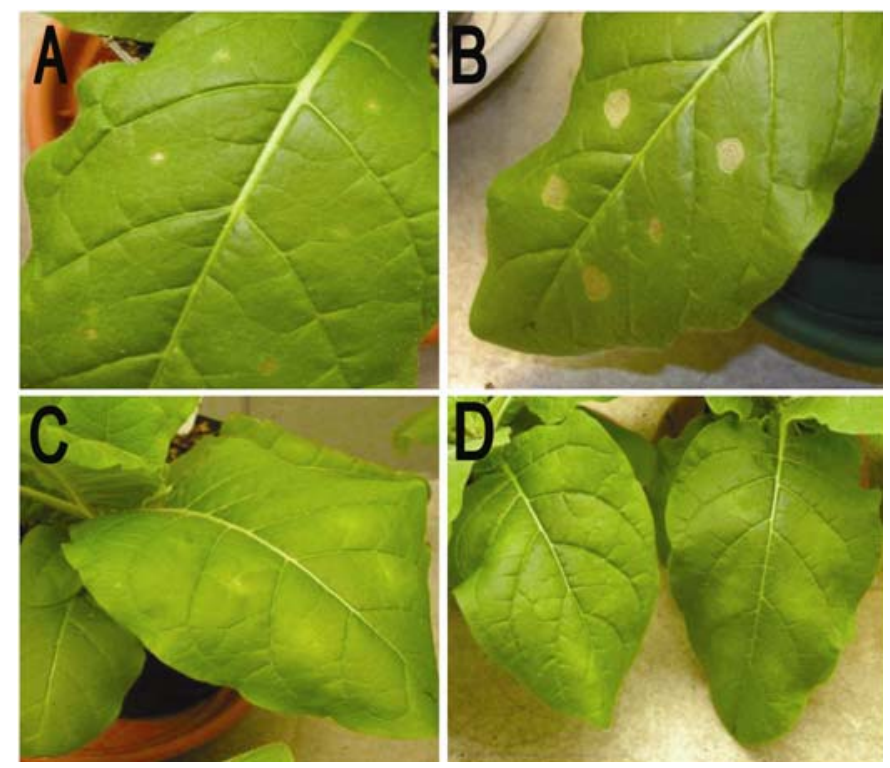

Fig. 1. Response of adult plants of Nicotiana langsdorffii to Peronospora tabacina infection (7 days postinoculation). A, S-4-2 and B, S-4-4 express a resistance phenotype in the form of an hypersensitive response (incompatible interactions), while C, S-4-3 and D, S-4-5 are highly susceptible to infection (compatible interactions). 
P. tabacina sporangia (Fig. 1). Accessions S-4-2 and S-4-6 showed a small necrotic spot ( 2 to $3 \mathrm{~mm}$ ) by $2 \mathrm{dpi}$, and the lesion size did not change over time. Morphologically identical lesions first appeared on leaves of S-4-4 at 2 dpi; however, these lesions gradually expanded in diameter over time in an unregulated manner, eventually reaching $\approx 5 \mathrm{~cm}$ in diameter, and were called "runaway" (compare the two upper panels in Fig. 1). Inoculation of accessions S-4-7, S-4-8, S-4-9, and S-4-10 resulted in small HR lesions on mature leaves, and spreading lesions on upper younger leaves of adult plants. Pathogen sporulation could not be induced on any of the plants that expressed an incompatible interaction with $P$. tabacina. Accession S-4-3 showed chlorotic lesions at 3 to $4 \mathrm{dpi}$ with heavy sporulation of $P$. tabacina after overnight incubation in darkness, while S-4-1 and S-4-5 showed the same symptoms at 6 to $8 \mathrm{dpi}$.

Soil-grown seedlings. Of $10 \mathrm{~N}$. langsdorffii accessions tested, seven developed necrotic lesions that appeared initially at 2 dpi on seedling leaves that had been drop inoculated with $P$. tabacina at 2 to 4 weeks after germination (Fig. 2). Lesions on accession S-4-2 remained small throughout the duration of the experiment. Inoculation of S-4-4, S-4-7, S-4-8, S-4-9, and S-4-10 resulted in necrotic lesions that expanded outward over time. Lesions on accessions S-4-7, S-4-8, S-4-9, and S-4-10 appeared water-soaked at 2 to $3 \mathrm{dpi}$; light sporulation occurred around the lesions on the leaves collected 5 dpi after overnight incubation in plastic bags. Accessions S-4-1, S-4-3, and S-4-5 consistently showed compatible interactions with $P$. tabacina, with production of chlorotic lesions on S-4-3 at 4 to 5 dpi followed by extensive, heavy sporulation after overnight incubation in plastic bags in the dark. Visible chlorosis did not become apparent at inoculation sites on S-4-1 and S-4-5 until 6 to 8 dpi, however, and pathogen sporulation was subsequently readily inducible as for S-4-3.

Cotyledons and leaves of seedlings grown in T-Medium. In cotyledon inoculations, six of eight tested accessions including S4-1 demonstrated an incompatible interaction with $P$. tabacina (Table 2). Browning around inoculation sites first appeared on cotyledons at 2 dpi except for S-4-1, where it was first observed at $4 \mathrm{dpi}$, and necrotic lesions were apparent at 5 dpi (Fig. 3). In contrast, accessions S-4-3 and S-4-10 showed a compatible interaction accompanied by heavy pathogen sporulation on cotyledon surfaces. In addition, tissue necrosis was observed on cotyledons of S-4-10. In leaf assays, all eight tested accessions responded with an incompatible interaction to $P$. tabacina infection except for S-4-1 and S-4-3. Pathogen sporulation was observed on seedling leaves of accession S-4-3 at 4 dpi and on S-4-1 at 6 dpi (Fig. 3).
Microscopic observation of $P$. tabacina in leaves of $N$. langsdorffii. To determine the cytological basis of the resistance observed in $N$. langsdorffii to P. tabacina infection, we examined the interactions in leaves of seedlings grown aseptically in 12-well plates microscopically by lactophenol-trypan blue staining after $P$. tabacina inoculation. At very early stages after $P$. tabacina inoculation, no visible differences were observed in responses of leaf tissues to P. tabacina at $6 \mathrm{hpi}$ or $12 \mathrm{hpi}$, except that granular cytoplasm started occurring at inoculation sites on S-4-2 (Fig. 4). Germination and growth of germ tubes were similar on all tested $N$. langsdorffii accessions and N. tabacum KY14. In S-4-2 and S4-4, increased staining of leaf tissues and granular cytoplasm were generally observed around pathogen hyphae at 24 hpi. After $48 \mathrm{hpi}$, a large amount of hyphae had developed in leaf tissues of KY14 and, to a lesser extent, in S-4-1. However, thickened (lignified) hyphae and heavily increased staining were evident in leaf tissues of S-4-2 and S-4-4, indicating the incompatible interactions. Viable hyphae of $P$. tabacina were mainly observed in lesion areas in leaves of S-4-4, S-4-7, S-4-9, and S-4-10 (data not shown), and this occurred outside of necrotic lesions at $96 \mathrm{hpi}$.

Endogenous SA in S-4-1 and S-4-4 in response to $P$. tabacina infection. Levels of endogenous free SA were similar in leaves of S-4-1, S-4-4, and $\mathrm{F}_{1}$ plants by 48 hpi (Fig. 5). Basic levels of SA, i.e., at $0 \mathrm{hpi}$, in leaves of $N$. langsdorffii were very low $(0.32$, 0.28 , and $0.29 \mu \mathrm{g} / \mathrm{g}$ fresh leaf tissue for $\mathrm{S}-4-1, \mathrm{~S}-4-4$, and the $\mathrm{F}_{1}$, respectively). At $72 \mathrm{hpi}$, however, the level in S-4-4 was fourfold higher than in S-4-1, and the level in $\mathrm{F}_{1}$ plants was 2.6-fold higher. Further increases in SA levels were detected in all tested plants at 120 hpi, i.e., 54, 406, and 293 times in S-4-1, S-4-4, and $F_{1}$ leaves compared to those prior to inoculation with pathogen $(0 \mathrm{hpi})$. The highest levels of SA were found in leaves of S-4-4 (114 $\mu \mathrm{g} / \mathrm{g}$ fresh weight) followed by the $F_{1}(56 \mu \mathrm{g} / \mathrm{g})$ and $\mathrm{S}-4-1(17 \mu \mathrm{g} / \mathrm{g})$.

Genetic segregation of resistance. One $\mathrm{F}_{2}$ population and two modified backcross $\left(\mathrm{BC}_{1}\right)$ populations segregating for HRmediated blue mold resistance were developed. The parental lines and the $\mathrm{F}_{1}$ were included in all experiments. In the first experiment, $78 \mathrm{~F}_{2}$ progeny plants were tested for their responses to blue mold infection. Results showed that 58 plants were resistant and 20 were susceptible to $P$. tabacina. A repeat experiment, using the same seed source, showed that of $90 \mathrm{~F}_{2}$ plants, 68 were resistant and 22 were susceptible to $P$. tabacina. A chi-square test of homogeneity $\left(\chi^{2}=0.03188 ; P=0.858\right)$ indicated that the two populations could be combined, giving an $\mathrm{R} / \mathrm{S}$ ratio of $3.0: 1$ (126:42), which exactly met the expectation for segregation of a single dominant resistance gene in an $\mathrm{F}_{2}$ population (Table 3).

TABLE 2. Reaction of Nicotiana langsdorffii accessions to infection by the blue mold pathogen, Peronospora tabacina

\begin{tabular}{|c|c|c|c|c|}
\hline N. langsdorffii accession & Cotyledon (T-Medium $)^{\mathrm{q}}$ & Leaf (T-Medium) & Seedling $^{\mathrm{r}}$ (Pro-Mix) & Adult plants (Pro-Mix) \\
\hline S-4-1 & $\mathrm{HR}^{\mathrm{t}}$ & $\mathrm{Sp}^{\mathrm{u}}$ (delayed) & $\mathrm{C}^{\mathrm{v}}$ (delayed) & $\mathrm{C}$ (delayed) \\
\hline S-4-2 & HR & HR & $\mathrm{HR}$ & HR \\
\hline S-4-3 & $\mathrm{Sp}$ & $\mathrm{Sp}$ & $\mathrm{C}$ & $\mathrm{C}$ \\
\hline S-4-4 & HR & HR & $\mathrm{N}$ (runaway)+Sp & HR (runaway) \\
\hline$S-4-5$ & $-{ }^{\mathrm{w}}$ & - & $\mathrm{C}$ (delayed) & $\mathrm{C}$ (delayed) \\
\hline S-4-6 & - & - & HR & HR \\
\hline S-4-7 & HR & HR & $\mathrm{N}(\mathrm{w})^{\mathrm{x}}+\mathrm{Sp}$ & $\mathrm{HR}^{\mathrm{y}}$ \\
\hline S-4-8 & HR & HR & $\mathrm{N}(\mathrm{w})+\mathrm{Sp}$ & $\mathrm{HR}^{\mathrm{y}}$ \\
\hline S-4-9 & HR & HR & $\mathrm{N}(\mathrm{w})+\mathrm{Sp}$ & $\mathrm{HR}^{\mathrm{y}}$ \\
\hline S-4-10 & $\mathrm{N}^{\mathrm{z}}+\mathrm{Sp}$ & HR & $\mathrm{N}(\mathrm{w})+\mathrm{Sp}$ & $\mathrm{HR}^{\mathrm{y}}$ \\
\hline KY 14 & $\mathrm{C}$ & $\mathrm{C}$ & $\mathrm{C}$ & $\mathrm{C}$ \\
\hline
\end{tabular}

q T-Medium: the medium used for tobacco seed germination developed at KTRDC.

$r$ Two- to four-week-old seedlings grown in Pro-Mix were inoculated with P. tabacina.

s Five- to seven-week-old plants grown in Pro-mix were used for inoculation with $P$. tabacina.

t HR: hypersensitive response.

u Sp: sporulation; delayed: 6 to 8 days after inoculation.

${ }^{v} \mathrm{C}$ : chlorotic lesions.

${ }^{w}$ Accession not assayed on the indicated tissue.

${ }^{x} \mathrm{~N}(w)$ : water-soaked necrotic lesions and sporulation after overnight incubation.

y Contained HR on older leaves, spreading HR on younger leaves.

${ }^{\mathrm{z}} \mathrm{N}$ : necrotic lesions. 
For the modified backcross population BC1-1, the $\mathrm{F}_{1}(\mathrm{~S}-4-1 \times$ S-4-4) was crossed with $N$. forgetiana $\mathrm{S}-11-2$, and R/S ratios were determined by inoculating 98 progeny plants with $P$. tabacina. Chi-square analysis of disease reaction data indicated a good fit to the $1: 1$ (resistant/susceptible) segregation ratio predicted for a single dominant gene for resistance to P. tabacina (Table 3). Further confirmation came from genetic segregation data in a second modified backcross population with N. alata S-1-4 (BC12; Table 3). Taking the data from the three populations together, we conclude that HR-mediated blue mold resistance in $N$. langsdorffii S-4-4 is to be due to the action of a single dominant gene that we have named NIRPT.

Chemical suppression of HR development. The observed inhibitory effects of $\mathrm{CoCl}_{2}\left(\mathrm{a} \mathrm{Ca}^{++}\right.$-channel blocker) and $\mathrm{NaSA}$ (an antioxidant) on HR development in $N$. langsdorffii accessions were diverse. Treatment with $\mathrm{CoCl}_{2}$ and $\mathrm{NaSA}$ at $0.5 \mathrm{mM}$ sig-

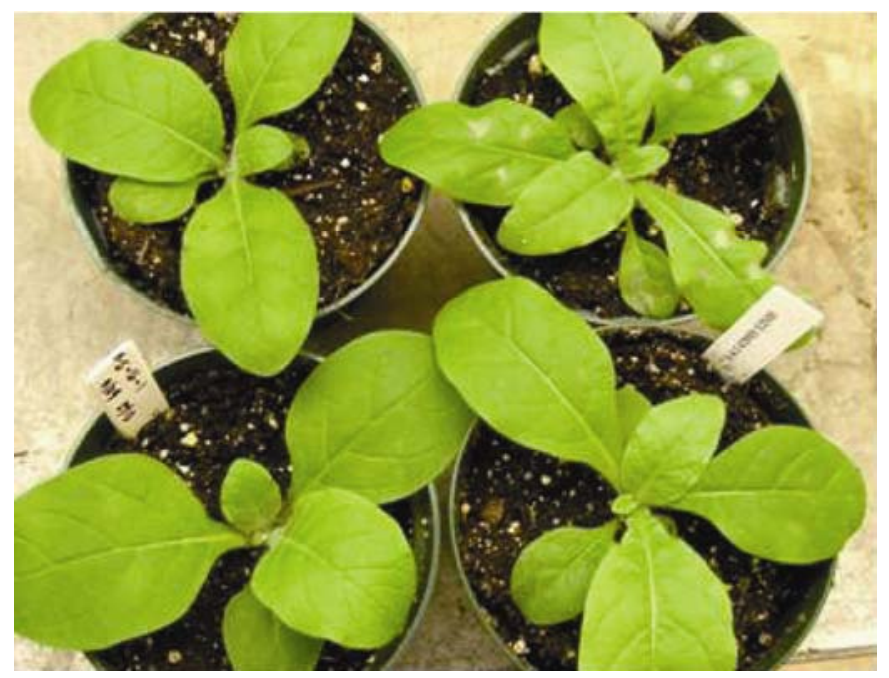

Fig. 2. Reaction expressed in young Nicotiana langsdorffii plants to Peronospora tabacina infection (5 days postinoculation). S-4-1 (bottom left) and S-4-3 (top left) are highly susceptible to infection (compatible interaction), while S-4-2 (bottom right) and S-4-4 (top right) express a resistance phenotype in the form of an hypersensitive response (incompatible interaction).
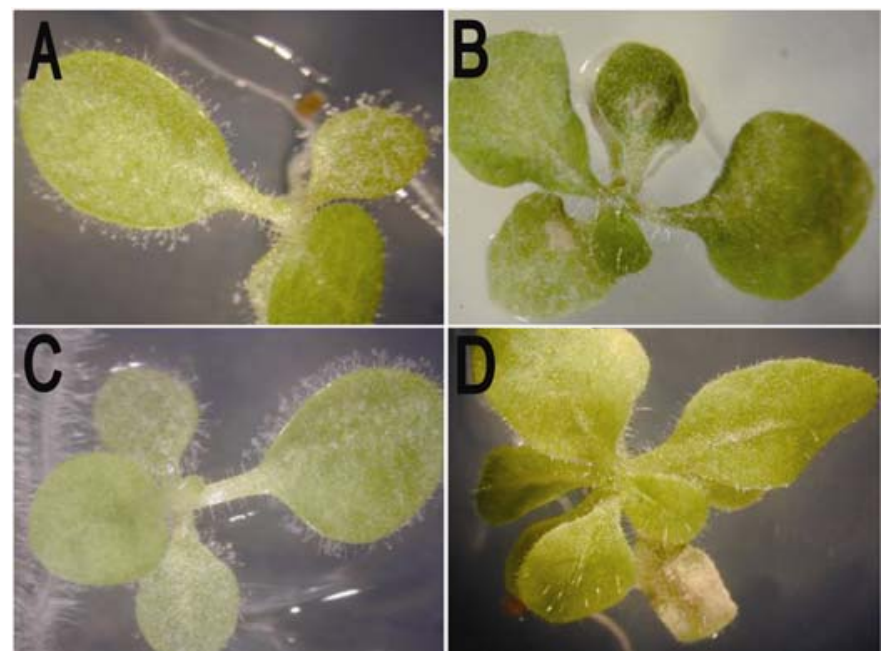

Fig. 3. Response of Nicotiana tabacum KY14 and N. langsdorffii seedlings grown in 12-well plates to Peronospora tabacina infection (4 days postinoculation). Seedlings were grown aseptically on T-medium and inoculated $\approx 3$ weeks after sowing. A, KY14 and C, $N$. langsdorffii S-4-3 are highly permissive hosts for $P$. tabacina. N. langsdorffii accessions B, S-4-2 and D, S4-4 respond to infection by expressing an hypersensitive response (HR; brown areas), and no pathogen sporulation (a resistant reaction). nificantly decreased the size (area) of necrotic lesions on S-4-2 and S-4-4 by 61 to $79 \%$ (Table 4). A lesser effect was observed at the lower concentration $(0.05 \mathrm{mM})$ for both compounds. Greater inhibition occurred on S-4-8 and S-4-10 treated with $\mathrm{CoCl}_{2}$ at $0.5 \mathrm{mM}$; very small or no lesions developed at the sites where $\mathrm{CoCl}_{2}$ was introduced. NaSA also significantly reduced lesion area at $0.5 \mathrm{mM}$, although less so than $\mathrm{CoCl}_{2}$. Treatment of S-4-9 with $0.5 \mathrm{mM} \mathrm{CoCl}_{2}$ resulted in a partial decrease in lesion size as
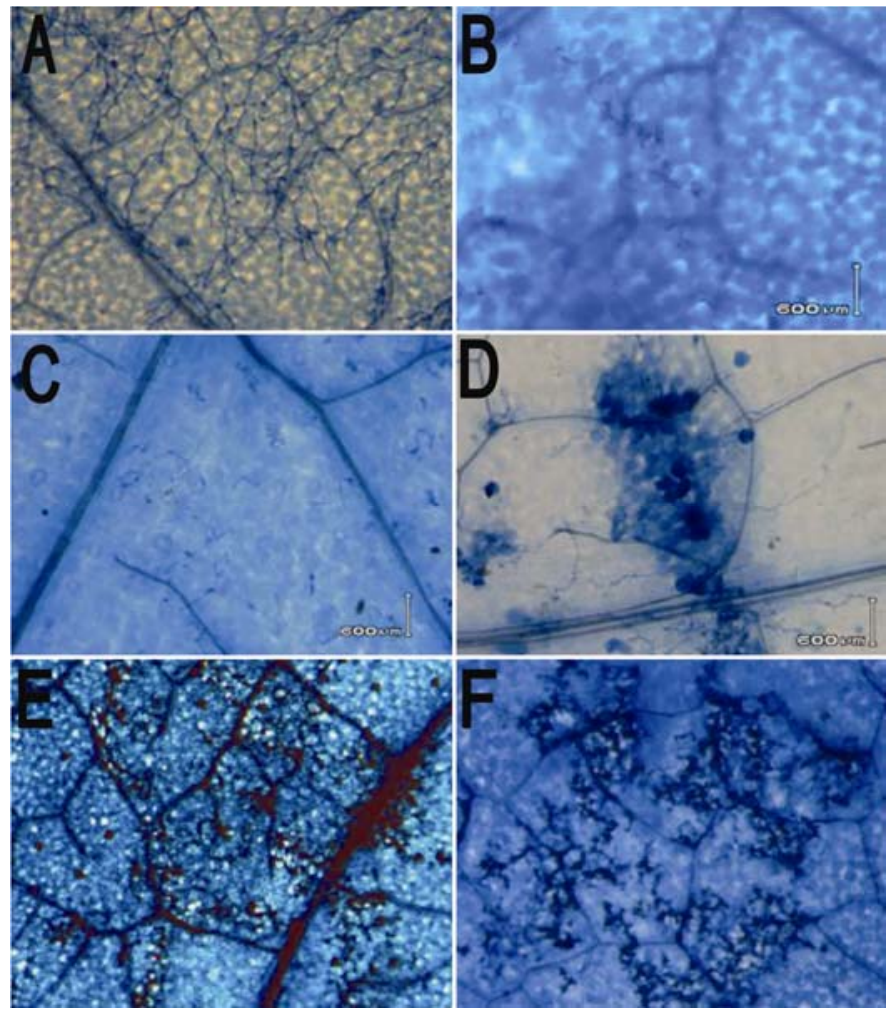

Fig. 4. Microscopic observations of Peronospora tabacina-infected leaves of Nicotiana tabacum KY14 and N. langsdorffii S-4-2 seedlings grown in 12-well plates after trypan blue staining. Panels show A, KY14 at $48 \mathrm{~h}$ postinoculation [hpi]) and B, N. langsdorffii S-4-2 at $6 \mathrm{hpi}, \mathbf{C}, 12 \mathrm{hpi}, \mathbf{D}$, 24 hpi, E, 48 hpi, and F, 96 hpi with $P$. tabacina sporangia. Leaf tissue was cleared and subsequently stained in trypan blue-lactophenol. Hyphae and dead or damaged host cells stain darker blue than does the surrounding plant tissue.

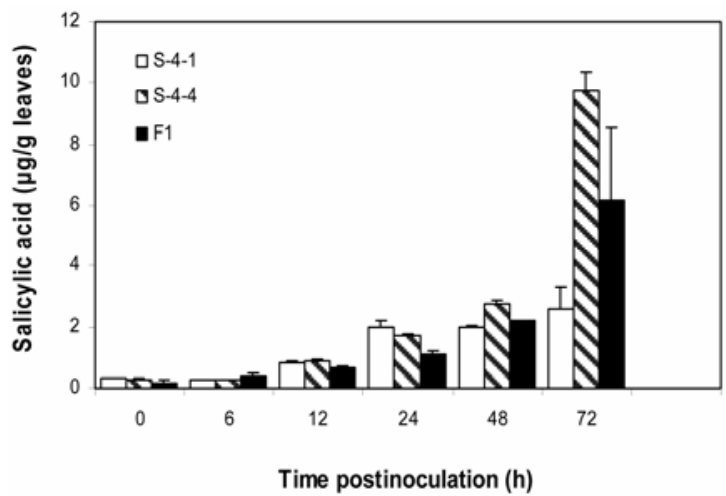

Fig. 5. Endogenous free salicylic acid (SA) in leaf tissues of Nicotiana langsdorffii following inoculation with Peronospora tabacina. Sporangia of $P$. tabacina were sprayed on leaves of S-4-1, S-4-4, and (S-4-1 $\times$ S-4-4) $\mathrm{F}_{1}$ plants. Leaf samples were collected at $0,6,12,24,48,72$, and 120 h postinoculation (hpi). Hypersensitive response lesions on S-4-4 and $\mathrm{F}_{1}$ plants became apparent at $48 \mathrm{hpi}$. Data presented here are average values from three experiments with three samples in each. Bars represent standard error of the mean. The extremely high values at $120 \mathrm{hpi}$ were removed for clarity. 
compared to S-4-8 and S-4-10, although the inhibition was still $96 \%$ compared to the water control.

Expression of the HSR203J homolog in $N$. langsdorffii. In general, HSR203J mRNA levels in $N$. langsdorffii leaves, as determined by reverse transcriptase-PCR and quantitative real-time PCR, increased with time after inoculation with P. tabacina (Figs. 6 and 7). HSR203J-specific transcripts in S-4-1 leaves accumulated steadily over time (Fig. 6), reaching levels that were 3- and 12-fold higher at 72 and $120 \mathrm{hpi}$, respectively, compared to the uninoculated control (Fig. 7). In S-4-4, the relative increase in transcription of this gene was even greater; 6 and 22 times the control value at 72 and $120 \mathrm{hpi}$, respectively (Fig. 7). Transcript levels in $\mathrm{F}_{1}$ leaves showed a similar time-dependent pattern, although the levels were intermediate between those observed for the two parental lines. Interestingly, a sharp decrease $(\approx 13$-fold $)$ in the abundance of $H S R 203 \mathrm{~J}$-specific transcripts was observed in S-4-4 at 6 hpi compared with the uninoculated control. The level of $H S R 203 \mathrm{~J}$ mRNA remained low at $12 \mathrm{hpi}$, and only returned to the basal level observed in the uninoculated control between 24 and $48 \mathrm{hpi}$. This repression of HSR203J-specific transcript levels is in marked contrast to what is observed for the $\alpha$-tubulin gene control, for which transcription appears to be essentially unaffected by $P$. tabacina infection. A nearly identical expression pattern-an early decline from basal levels followed by a rapid rise in mRNA levels beginning at 2 to $3 \mathrm{dpi}$-was also observed for $P R-1 a$, another gene known to be induced during incompatible plant-pathogen interactions in $N$. langsdorffii S-4-4 following P. tabacina infection (data not shown).

\section{DISCUSSION}

This is the first report of dominant, monogenic resistance to tobacco blue mold disease in any species of Nicotiana. The data presented here clearly shows that infection by the biotrophic oömycete Peronospora tabacina resulted in an incompatible hostpathogen interaction on some accessions of $N$. langsdorffii, a wild relative of cultivated tobacco that is native to South America. We

TABLE 3. Genetic segregation of hypersensitive response-mediated resistance to Peronospora tabacina in three populations of Nicotiana langsdorffii

\begin{tabular}{|c|c|c|c|c|c|c|}
\hline \multirow[b]{2}{*}{ Population } & \multirow[b]{2}{*}{ Type } & \multicolumn{5}{|c|}{ Expected } \\
\hline & & $\mathrm{R}$ & $\mathrm{S}$ & $\mathrm{R}: \mathrm{S}$ & $\chi^{2}$ & $P$ \\
\hline$(\mathrm{S}-4-1 \times \mathrm{S}-4-4)$ & $\mathrm{F}_{2}^{\mathrm{y}}$ & 126 & 42 & $3: 1$ & - & - \\
\hline $\begin{array}{l}(\mathrm{S}-4-1 \times \mathrm{S}-4-4) \times \\
\quad N . \text { forgetiana } \mathrm{S}-11-2 \\
(\mathrm{~S}-4-1 \times \mathrm{S}-4-4) \times\end{array}$ & $\mathrm{BC}_{1}^{\mathrm{z}}$ & 46 & 52 & $1: 1$ & 0.18 & 0.67 \\
\hline N. alata S-1-4 & $\mathrm{BC}_{1}^{\mathrm{z}}$ & 36 & 44 & $1: 1$ & 0.40 & 0.53 \\
\hline
\end{tabular}

${ }^{y}$ Data were combined from two separate experiments.

${ }^{\mathrm{z}}$ Data were collected from a single experiment. have shown that this resistance is mediated by expression of the $\mathrm{HR}$, and that the phenotype is due to the presence of a single dominant gene (NIRPT) in N. langsdorffii S-4-4. Most significantly, accessions such as S-4-2 and S-4-4 are fully resistant to blue mold infection at very early stages of growth, making NIRPT a potential candidate gene for management of blue mold disease by incorporation of this gene into cultivated tobacco. Blue mold

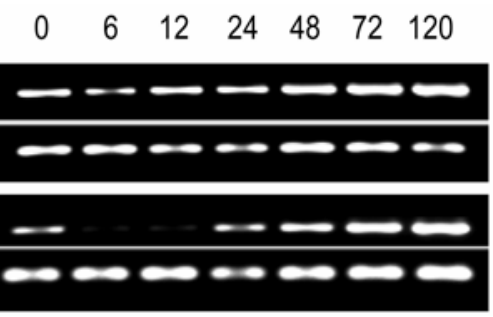

Fig. 6. Results of end-point reverse transcriptase polymerase chain reaction (PCR) analysis of HSR203J mRNA accumulation in Nicotiana langsdorffii. Real time PCR analysis was performed with cDNA synthesized from total RNA isolated from leaves of $N$. langsdorffii S-4-1 and S-4-4 at 0, 6, 12, 24, 48,72 , and 120 h postinoculation with $P$. tabacina $\left(10^{4}\right.$ sporangia/ml). Amplification products were detected by agarose gel electrophoresis.

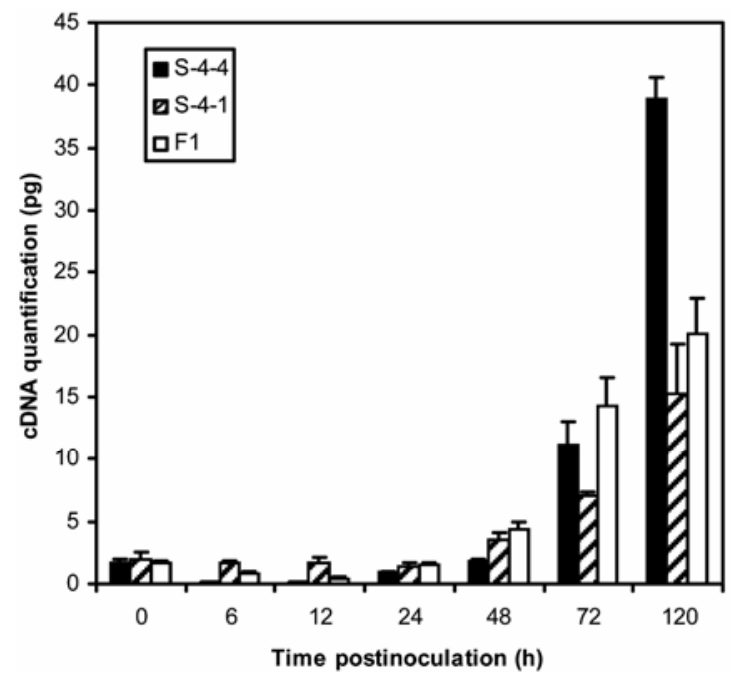

Fig. 7. Quantitative real-time polymerase chain reaction of HSR203J mRNA accumulation in Nicotiana langsdorffii leaves after inoculation with Peronospora tabacina. Leaves of S-4-1, S-4-4, and (S-4-1 $\times$ S-4-4) $F_{1}$ plants were inoculated with $P$. tabacina sporangia $\left(10^{4} / \mathrm{ml}\right.$ in water) and tissue samples were collected at $0,6,12,24,48,72$, and $120 \mathrm{~h}$ postinoculation. Data presented here are average values of $H S R 203 J$ cDNA (pg) from three experiments. Bars represent the standard deviation.

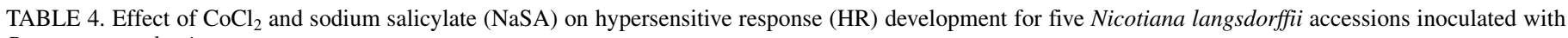
Peronospora tabacina

\begin{tabular}{|c|c|c|c|c|c|c|}
\hline \multirow[b]{2}{*}{ Treatment ${ }^{\mathrm{y}}$} & \multirow[b]{2}{*}{ Concentration (mM) } & \multicolumn{5}{|c|}{ Lesion diameter in $\mathrm{cm}(\% \text { decline in lesion area })^{\mathrm{z}}$} \\
\hline & & S-4-2 & S-4-4 & S-4-8 & S-4-9 & S-4-10 \\
\hline $\mathrm{CoCl}_{2}$ & 0.5 & $0.25 \mathrm{~b}(79)$ & $0.84 \mathrm{~b}(66)$ & 0.03 c (99.6) & 0.23 c (96) & $0.07 \mathrm{c}(99.4)$ \\
\hline $\mathrm{NaSA}$ & 0.05 & 0.48 a (21) & $1.29 \mathrm{a}(20)$ & $0.30 \mathrm{~b}(64)$ & $0.90 \mathrm{~b}(64)$ & $0.57 \mathrm{~b}(57)$ \\
\hline Control $\left(\mathrm{H}_{2} \mathrm{O}\right)$ & 0.5 & $0.27 \mathrm{~b}(75)$ & $0.90 \mathrm{~b}(61)$ & $0.30 \mathrm{~b}(64)$ & $0.90 \mathrm{~b}(47)$ & $0.53 \mathrm{~b}(63)$ \\
\hline \multirow[t]{3}{*}{$\mathrm{LSD}_{0.05}$} & 0.05 & 0.45 a (31) & $1.23 \mathrm{a}(27)$ & $0.53 \mathrm{a}(0)$ & $1.03 \mathrm{~b}(30)$ & $0.80 \mathrm{ab}(15)$ \\
\hline & $\ldots$ & $0.54 \mathrm{a}$ & $1.44 \mathrm{a}$ & $0.50 \mathrm{a}$ & $1.23 \mathrm{a}$ & $0.87 \mathrm{a}$ \\
\hline & $\ldots$ & 0.17 & 0.28 & 0.23 & 0.20 & 0.30 \\
\hline
\end{tabular}

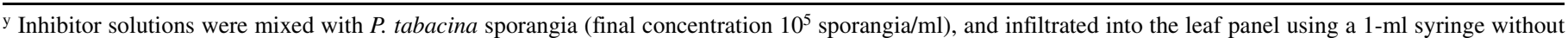
needle.

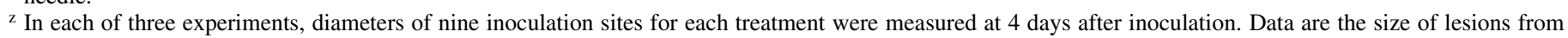
each treatment, averaged across the three experiments in which each contained three plants. Mean values within the columns followed by different letters are

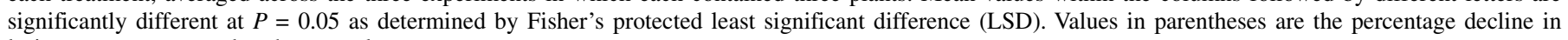
lesion area as compared to the control. 
resistance was discovered in accession S-4-4 during routine plant inoculations with $P$. tabacina sporangia. Genetic crosses to determine the mode of inheritance of the HR phenotype were made with S-4-4 before we had identified other blue mold resistant accessions of $N$. langsdorffii (such as S-4-2 and S-4-6). We were also initially unaware of the significance of the "runaway" lesion phenotype expressed by S-4-4. S-4-2 may be a better source for a blue mold resistance gene, and we are in the process of determining whether the regulated HR expressed by this accession in response to $P$. tabacina infection is due to a different $\mathrm{R}$ gene or another allele of $N I R P T$.

To our knowledge, NIRPT is only the second gene known to condition HR-mediated resistance (incompatibility) to $P$. tabacina in the genus Nicotiana. Unlike rptl from N. obtusifolia (13), NIRPT is inherited in a dominant fashion, a characteristic it shares with the majority of plant R-genes that provide resistance to oömycete pathogens. Examples of dominant R-genes in the Solanaceae are $R I$ and $R 3 a$ from Solanum demissum Lindley $(1,15)$ and $R B$ from $S$. bulbocastanum Dunal $(46)$, three genes that confer race-specific resistance to potato late blight (caused by Phytophthora infestans (Mont. de Bary). Dominant genes specifying resistance to the oömycetes Peronospora parasitica (Pers.:Fr.) Fr. and Bremia lactucae Regel have been cloned from Arabidopsis and lettuce, respectively, and as with $R 1, R 3 a$, and $R B$, have been shown to be members of the general class of plant $\mathrm{R}$ genes containing putative nucleotide binding site and leucine rich repeat (NBS-LRR) domains (30). Therefore, strategies that exploit the mapping of NBS-LRR resistance gene analogs (RGAs) could be applied to isolation of NIRPT via positional gene cloning in $N$. langsdorffii. $\mathrm{R}$ gene cloning from species with large genomes (such as tobacco and potato) is by no means routine, and generally requires that candidate genes and/or gene clusters be identified in physical bacterial artificial chromosome (BAC) clone contigs that also carry tightly linked molecular markers (34).

The HR, a localized form of programmed cell death (PCD), is a common outcome of genetic incompatibility between a resistant host and an avirulent microbial pathogen. Specific interactions between plant R-gene and pathogen Avr gene products (elicitors or effectors) result in sudden, irreversible death of infected host cells and accompanying death or suppression of the invading pathogen. The HR is cell-autonomous, requires active host metabolism, and represents the final stage of a complex series of events characterized by rapid membrane ion fluxes, production of reactive oxygen intermediates, deposition of phenolic compounds, fragmentation of nuclear DNA, cytoplasmic disorganization, and eventual cell death (12,33). Incompatible interactions involving biotrophic fungal or oömycete pathogens that form intimate associations with the host through haustoria typically result in elevated levels of SA and rapid transcriptional induction of a suite of defense- related genes (e.g., PR protein genes, etc.). We have shown here that both endogenous SA levels and transcription of $H S R 203 J$, a gene known to be rapidly induced during incompatible host-pathogen interactions in tobacco (36) and sunflower (37), increased markedly over time from basal levels in blue mold resistant $N$. langsdorffii S-4-4, but much less so in susceptible S4-1, following inoculation with $P$. tabacina. The most significant increase in the levels of SA and HSR203J-specific mRNA occurred between 3 and $5 \mathrm{dpi}$, well after the appearance of the HR on S-4-4. This could be reflective of the SA levels required for establishment of SAR in $N$. langsdorffii. In tobacco ( $N$. tabacum) expressing $N$ gene-determined incompatibility to TMV, SAR is first detectable in systemic leaves 2 dpi with TMV, reaches its maximum at 7 to 10 days, and persists for at least 20 days (40). Curiously, transcription of HSR203J declined rapidly from 0 hpi to barely detectable levels at 6 and $12 \mathrm{hpi}$, and only returned to the initial ( $0 \mathrm{hpi}$ ) level between 24 and $48 \mathrm{hpi}$. In inoculated leaves of $N$. tabacum, early events in the P. tabacina infection cycle such as sporangial germination and host penetration occur very quickly, within $\approx 2.5 \mathrm{hpi}$, and invasion of the pathogen into the intercellular space occurs by 4 hpi. The first haustoria form sometime later, possibly as soon as $6 \mathrm{hpi}$, when the hyphae come into contact with host mesophyll cells $(31,49)$. Susceptible genotypes of $N$. langsdorffii are excellent hosts for this pathogen, so we could expect similar timing of events for $P$. tabacina infection. Therefore, for the transcriptional repression or accelerated mRNA degradation of HSR203J (and possibly other defense-related genes) to occur in S-4-4 by $6 \mathrm{hpi}$, the invading pathogen must be communicating with the host cells during the early phases of intercellular hyphal growth. In A. thaliana plants infected with Peronospora parasitica, haustoria were observed in penetrated epidermal and/or mesophyll cells in both compatible and incompatible interactions by $1 \mathrm{dpi}$, but unfortunately no observations were made earlier in the infection process (47). We have also observed a transient reduction in mRNA pools for the $P R$ - $l a$ gene homolog (data not shown), and further investigation is underway to determine whether this phenomenon can be generalized for genes that are induced or up-regulated during the $P$. tabacinainduced HR.

At the present time, we do not know what effector molecule(s) actually trigger the HR in $N$. langsdorffii S-4-4 following inoculation with $P$. tabacina. Small proteins produced by species of Phytophthora, another genus of oömycete plant pathogens, have been shown to induce both race-specific and nonhost specific HR in species of Nicotiana and other members of the Solanaceae $(22,55)$. Intercellular fluid (ICF) washes and total protein extracts from $P$. tabacina-infected leaves of $N$. tabacum KY14 and $N$. langsdorffii S-4-3 failed to induce an HR-like response when infiltrated into leaves of $N$. langsdorffii S-4-4, although ICF extracted from plants at 5 dpi contained an activity that induced rapid necrosis on leaves of $N$. obtusifolia PI 555573 (data not shown). $\mathrm{CoCl}_{2}$, a calcium-channel blocker, and NaSA, an antioxidant, significantly reduced the area of HR lesions (66 to $>99 \%$ and 47 to $75 \%$, respectively) in five resistant accessions of $N$. langsdorffii when co-infiltrated at $0.5 \mathrm{mM}$ with $P$. tabacina sporangia (Table 4). A similar effect was observed for $\mathrm{CoCl}_{2}$ in $P$. tabacina infected plants of $N$. obtusifolia PI 555573, and the interpretation was that $\mathrm{CoCl}_{2}$ blocked the influx of $\mathrm{Ca}^{++}$across the plasma membrane, which is known to be required for establishment of the HR (13). Recent advances in Phytophthora genomics have led to an increased awareness of the number of proteins that are secreted directly into host cells via the haustorial interface (20), a situation that is somewhat analogous to the type-III secretory system (TTSS) machinery of plant pathogenic and symbiotic bacteria (2). Invading oömycete plant pathogens secrete protein effectors into both the apoplast and the host cell cytoplasm, and these molecules then function to redirect or reprogram normal plant cell defenses (20). Approximately 350 effector-like genes have been identified in the genomes of both $P$. sojae and $P$. ramorum, providing evidence that a large number of proteins may be delivered to host cells during pathogen colonization (51). Therefore, our present hypothesis is that P. tabacina secretes one or more avirulence gene products directly into host cells, and one or more of these effectors are then recognized by the NIRPT resistance gene product in the cytoplasm of $N$. langsdorffii S-4-4 and possibly other resistant host genotypes (S-4-2, S-4-6, etc.), triggering a cascade of molecular events that results in localized cell death.

The host-pathogen interactions observed between $P$. tabacina and a group of $N$. langsdorffii accessions can be grouped into five general classes based on observed responses: (i) fully compatible with rapid pathogen colonization and sporulation (S-4-3), (ii) fully compatible with delayed symptom development and sporulation (S-4-5), (iii) fully incompatible, with HR appearing at $48 \mathrm{hpi}$ and no further lesion expansion and no sporulation (S-4-2 and S-4-6), (iv) incompatible, HR appears at 48 hpi and continues 
to expand until leaf becomes senescent, no pathogen sporulation (S-4-4 and S-4-7 through S-4-10), and (v) differential expression of host response beginning with incompatibility (HR) on cotyledons progressing to full compatibility by 6 to 7 weeks of age (S4-1). A striking feature of classes iii and iv is that HR-mediated blue mold resistance is expressed in plants at very young ages, even in cotyledon tissue (also seen in class v). In Brassica oleracea, Coelho and Monteiro (8) reported five classes of interaction phenotypes with two pathovars of the downy mildew pathogen $P$. parasitica. Resistance at the cotyledon stage was observed in five of the seven host accessions tested, but this trait was a good predictor of adult plant resistance for only one of the two isolates of the pathogen included in the study.

Age-dependent development of host resistance to blue mold and black shank diseases, caused by the two major oömycete pathogens of tobacco, is well documented in the literature. Plants at or near the flowering stage are far less susceptible to $P$. tabacina infection than are younger plants, with reductions observed in both lesion number and the intensity of pathogen sporulation (38). For the black shank pathogen, P. parasitica var. nicotianae, foliar resistance develops as the plant becomes committed to flowering, and this is correlated with an SA-independent cytotoxic activity present in the ICF (16). A similar developmental dependency was also observed for expression of the HR following blue mold infection in resistant $N$. obtusifolia; plants of accession 555573 that were 4 weeks of age and younger gave a fully compatible interaction with $P$. tabacina, but the nature of the interaction changed to incompatibility with the plants expressing full resistance (HR) at 5 weeks of age and beyond (13).

An interesting observation made during these studies is that several accessions of $N$. langsdorffii responded to $P$. tabacina infection with a "runaway" or unregulated HR, and this was the case with S-4-4, the source of resistance gene NIRPT. As with S4-2 and S-4-6, the initial HR appeared on S-4-4 leaves 48 hpi with $P$. tabacina. Unlike these two accessions, however, HR lesions on S-4-4 continued to expand at the margins, with a new ring of necrotic tissue appearing approximately every day. After 2 to 3 weeks, the leaf senesced, as evidenced by rapid yellowing, and often collapsed precipitously. A recent paper (27) reports a similar phenomenon in TMV-infected plants of $N$. benthamiana Domin carrying the resistance gene $N$ in which the plant homolog of human BECLIN-1 has been silenced. This study showed that HR-dependent PCD in this system is due to autophagy, and that $B E C L I N-1$ is required for both induction of autolysosomes and subsequent restriction of PCD to the site of induction. This work suggests that there is a mobile signal produced at the site of HR initiation, but that the mechanism for containing this signal, and thus HR-dependent PCD, is lost in plants silenced for BECLIN-1. A similar "runaway" HR phenotype was seen in the $l s d l$ mutant of Arabidopsis when grown under long day (16 h photoperiod) conditions, and also when nonlesioned (short day grown) plants were inoculated with $P$. parasitica (9). In this system, superoxide was required for lesion development and subsequent propagation (17), and two genes known to be involved in disease resistance signaling (EDS1 and PAD4) were found to be essential components of the cell death pathway regulated by LSD1 (43). LSD1 encodes a zinc finger-type protein that somehow functions to negatively regulate the spread of PCD during the HR, and its relationship to the process of autophagy is unknown. For N. langsdorffii S-4-4, experiments are underway to determine whether the spreading HR phenotype that occurs as a result of $P$. tabacina infection is due to unregulated autophagy, or possibly some other mechanism in this species.

The "runaway" HR observed on $P$. tabacina infected plants of $N$. langsdorffii S-4-4 is interesting because it shows a possible link between the PCD of pathogen-induced incompatibility and the PCD that occurs due to senescence (36). We observed yellowing, indicative of senescence, around runaway HR lesions on
P. tabacina-inoculated leaves of S-4-4. The senescence progressed over the course of 2 to 3 weeks, and the inoculated leaf collapsed and died. To determine whether the unregulated HR was specific to this host-pathogen interaction, we infiltrated leaves of several $N$. langsdorffii accessions with culture filtrates of $E$. coli expressing the $P$. infestans elicitor INF1 $(21,22)$. All accessions of $N$. langsdorffii, regardless of their response to $P$. tabacina infection, developed necrotic lesions within 3 days following infiltration with INF1. N. langsdorffii is known to be sensitive to Phytophthora elicitins (23), as well as INF1 (S. Kamoun, personal communication). S-4-4 displayed a more intense reaction to INF1 than did other accessions that are susceptible (S-4-1 and S-4-3) or resistant (S-4-2) to P. tabacina. Necrotic lesions on S-4-4 appeared sooner and were initially larger than those on the other three accessions, and they mimicked the developmental sequence observed for blue mold-induced lesions on this accession in that they continued to expand over time, eventually resulting in senescence and death of the leaf, while those on S-4-1, S-4-2, and S-4-3 did not (data not shown).

As a final note, it is worth considering why HR-mediated blue mold resistance was not previously reported in $N$. langsdorffii. Beginning in the 1930s, blue mold disease of tobacco was seen as an economic threat to United States farmers, and as a consequence, government researchers initiated a search for sources of genetic resistance to the pathogen. The disease was first reported from tobacco seedbeds in Georgia and Florida in 1921, but was not seen again until 1931, after which time it became a widespread pest on flue-cured tobacco in the southeastern United States (48). Comprehensive screening of $N$. tabacum germplasm began in 1933 and continued for many years. The general methodology employed at that time was to grow plants in seedbeds or in the greenhouse, spray inoculate them with concentrated suspensions of $P$. tabacina sporangia, and look for survivors. Useful genetic resistance was not detected in any of the $>1,000$ collections of N. tabacum treated in this fashion (4). However, six species of Nicotiana from Australia (all in Section Suaveolentes) were found to be resistant or immune. Clayton noted that seedlings of three of these species were highly susceptible to blue mold infection, and that resistance developed with increasing seedling age (4). Curiously, he rated two members of Nicotiana Section Alatae, N. longiflora Cav. and N. plumbaginifolia, in the highly resistant class. We inoculated several accessions of both species and found that all were heavily colonized by $P$. tabacina and supported heavy pathogen sporulation, findings which are contrary to Clayton's results (D. Zaitlin and S. Zhang, unpublished data). N. langsdorffii was rated as slightly resistant (the class next to fully susceptible) in Clayton's survey. Seventy percent of the $N$. langsdorffii accessions we inoculated developed an HR when infected by $P$. tabacina and are therefore highly resistant to tobacco blue mold disease. Because none of the accessions used by Clayton were identified, he must have used a compatible host genotype (such as S-4-1, S-4-3, or S-4-5) or he was unfamiliar with the paradigm of host-pathogen incompatibility and failed to recognize the $\mathrm{HR}$ as true resistance. We speculate that had he used a genotype of $N$. langsdorffii carrying $N I R P T$ (or a similar gene), plants that were spray inoculated with $P$. tabacina sporangia would have expressed widespread hypersensitivity and collapsed 2 to $3 \mathrm{dpi}$. These plants would appear to have succumbed to pathogen infection and would probably have been considered susceptible to blue mold disease.

\section{ACKNOWLEDGMENTS}

The authors thank KTRDC director H. M. Davies and the Kentucky Tobacco Research Board (KTRB) for research funding, R. Babbitt and Q. (Willa) Huang for technical assistance, P. Rice, B. Kinney, and C. Cooper for maintaining plants in the greenhouse, and I. B. Maiti and S. Raha for assistance with real-time PCR. 


\section{LITERATURE CITED}

1. Ballvora, A., Ercolano, M. R., Weiß, J., Meksum, K., Bormann, C. A., Oberhagemann, P., Salamini, F., and Gebhardt, C. 2002. The Rl gene for potato resistance to late blight (Phytophthora infestans) belongs to the leucine zipper/NBS/LRR class of plant resistance genes. Plant J. 30:361371.

2. Bartsev, A. V., Deakin, W. J., Boukli, N. M., McAlvin, C. B., Stacey, G., Malnoë, P., Broughton, W. J., and Staehelin, C. 2004. NopL, an effector of Rhizobium sp. NGR234 thwarts activation of plant defense reactions. Plant Physiol. 134:871-879.

3. Berry, J. W., and McKean, W. E. 1985. Development of Peronospora hyoscyami f. sp. tabacina in the resistant host Nicotiana exigua. Can. J. Plant Pathol. 7:262-269.

4. Clayton, E. E. 1945. Resistance of tobacco to blue mold (Peronospora tabacina). J. Agric. Res. 70:79-87.

5. Clayton, E. E. 1967. The transfer of blue mold resistance to tobacco from Nicotiana debneyi. Part III. Development of a blue mold resistant cigar wrapper variety. Tobacco Sci. 11:107-110.

6. Clayton, E. E. 1968. The transfer of blue mold resistance to tobacco from Nicotiana debneyi. Part IV. Breeding programs 1957-1967. Tobacco Sci. 12:112-124.

7. Clayton, E. E., Heggestad, H., Grosso, J. J., and Burk, L. G. 1967. The transfer of blue mold resistance to tobacco from Nicotiana debneyi. Part I. Breeding progress 1937-1954. Tobacco Sci. 11:91-97.

8. Coelho, P. S., and Monteiro, A. A. 2003. Expression of resistance to downy mildew at cotyledon and adult plant stages in Brassica oleracea L. Euphytica 133:279-284.

9. Dietrich, R. A., Delaney, T. P., Uknes, S. J., Ward, E. R., Ryals, J. A., and Dangl, J. L. 1994. Arabidopsis mutants simulating disease resistance response. Cell 77:565-577.

10. Dinesh-Kumar, S. P., Whitham, S., Choi, D., Hehl, R., Corr, C., and Baker, B. 1995. Transposon tagging of tobacco mosaic virus resistance gene $N$ : Its possible role in the TMV- $N$-mediated signal transduction pathway. Proc. Natl. Acad. Sci. USA 92:4175-4180.

11. Goodspeed, T. H. 1954. The Genus Nicotiana: Origins, Relationships and Evolution of Its Species in the Light of Their Distribution, Morphology and Cytogenetics. Chronica Botanica, Waltham, MA.

12. Hammond-Kosack, K. E., and Jones, J. D. G. 1996. Resistance genedependent plant defense responses. Plant Cell 8:1773-1791.

13. Heist, E. P., Zaitlin, D., Funnell, D. L., Nesmith, W. C., and Schardl, C. L. 2004. Necrotic lesion resistance induced by Peronospora tabacina on leaves of Nicotiana obtusifolia. Phytopathology 94:1178-1188.

14. Holmes, F. O. 1938. Inheritance of resistance to tobacco-mosaic disease in tobacco. Phytopathology 28:553-561.

15. Huang, S., van der Vossen, E. A. G., Kuang, H., Vleeshouwers, V. G. A. A., Zhang, N., Borm, T. J. A., van Eck, H. J., Baker, B., Jacobsen, E., and Visser, R. G. F. 2005. Comparative genomics enabled the isolation of the $R 3 a$ late blight resistance gene in potato. Plant J. 42:251-261.

16. Hugot, K., Aime, S., Conrod, S., Poupet, A., and Galiana, E., 1999. Developmental regulated mechanisms affect the ability of a fungal pathogen to infect and colonize tobacco leaves. Plant J. Cell Mol. Biol. 20:163-170.

17. Jabs, T., Dietrich, R A., and Dangl, J. L. 1996. Initiation of runaway cell death in an Arabidopsis mutant by extracellular superoxide. Science 273:1853-1856.

18. Johnson, G. I. 1989. Peronospora hyoscyami De Bary: Taxonomic history, strains and host range. Pages 1-18 in: Blue Mold of Tobacco. W. E. McKean, ed. American Phytopathological Society, St. Paul, MN.

19. Johnson, E. S., Wolff, M. F., and Wernsman, E. A. 2002. Origin of the black shank resistance gene, $P h$, in tobacco cultivar Coker 371-Gold. Plant Dis. 86:1080-1084.

20. Kamoun, S. 2006. A catalogue of the effector secretome of plant pathogenic oomycetes. Annu. Rev. Phytopathol. 44:41-60.

21. Kamoun, S., van West, P., de Jong, A. J., de Groot, K. E., Vleeshouwers, V. G. A. A., and Govers, F. 1997. A gene encoding a protein elicitor of Phytophthora infestans is down-regulated during infection of potato. Mol. Plant-Microbe Interact. 10:13-20.

22. Kamoun, S., van West, P., Vleeshouwers, V. G. A. A., de Groot, K. E., and Govers, F. 1998. Resistance of Nicotiana benthamiana to Phytophthora infestans is mediated by the recognition of the elicitor protein INF1. Plant Cell 10:1413-1425.

23. Kamoun, S., Young, M., Glascock, C. B., and Tyler, B. M. 1993. Extracellular protein elicitors from Phytophthora: Host-specificity and induction of resistance to bacterial and fungal phytopathogens. Mol. Plant-Microbe Interact. 6:15-25.

24. Kenward, K. D., Bai, D., Ban, M. R., and Brandle, J. E. 1999. Isolation and characterization of Tnd-1, a retrotransposon marker linked to blank root rot resistance in tobacco. Theor. Appl. Genet. 98:387-395.
25. Keogh, R. C., Deverall, B. J., and McLeod, S. 1980. Comparison of histological and physiological responses to Phakopsora pachyrhizi in resistant and susceptible soybean. Trans. Br. Mycol. Soc. 74:329333.

26. Lea, H. W. 1963. The transfer of resistance against blue mold (Peronospora tabacina Adam) from Nicotiana debneyito cultivated tobacco. CORESTA Inf. Bull. 1963:13-15.

27. Liu, Y., Schiff, M., Czymmek, K., Tallóczy, Z., Levine, B., and DineshKumar, S. P. 2005. Autophagy regulates programmed cell death during the plant innate immune response. Cell 121:567-577.

28. Lucas, G. B. 1980. The war against blue mold. Science 210:147-153.

29. Main, C. E. 1998. Blue mold. Pages 5-9 in: Compendium of Tobacco Diseases. H. D. Shew and G. B. Lucas, eds. American Phytopathological Society, St. Paul, MN.

30. Martin, G. B., Bogdanove, A. J., and Sessa, G. 2003. Understanding the functions of plant disease resistance proteins. Annu. Rev. Plant Biol. 54:23-61.

31. McKeen, W. E., and Svircev, A. M. 1981. Early development of Peronospora tabacina in the Nicotiana tabacum leaf. Can. J. Plant Pathol. 3:145-158.

32. Milla, S. R., Levin, J. S., and Rufty, R. C. 2005. RAPD and SCAR markers linked to an introgressed gene conditioning resistance to Peronospora tabacina D. B. Adam in tobacco. Crop Sci. 45:2346-2354.

33. Mittler, R., Simon, L., and Lam, E. 1997. Pathogen-induced programmed cell death in tobacco. J. Cell Sci. 110:1333-1344.

34. Peters, J., Cnudde, F., and Gerats, T. 2003. Forward genetics and mapbased cloning approaches. Trends Plant Sci. 8:484-491.

35. Pontier, D., Godiard, L., Marco, Y., and Roby, D. 1994. HSR203J, a tobacco gene whose activation is rapid, highly localized and specific for incompatible plant/pathogen interactions. Plant J. 5:507-521.

36. Pontier, D., Gan, S., Amasino, R. M., Roby, D., and Lam, E. 1999. Markers for hypersensitive response and senescence show distinct patterns of expression. Plant Mol. Biol. 39:1243-1255.

37. Radwan, O., Mouzeyar, S., Venisse, J. S., Nicolas, P., and Bouzidi, M. F. 2005. Resistance of sunflower to the biotrophic oomycete Plasmopara halstedii is associated with a delayed hypersensitive response within the hypocotyls. J. Exp. Bot. 56:2683-2693.

38. Reuveni, M., Nesmith, W. C., and Siegel, M. R. 1986. Symptom development and disease severity in Nicotiana tabacum and $N$. repanda caused by Peronospora tabacina. Plant Dis. 70:727-729.

39. Rice, C. E., and Baker, M. S. 1991. The effects of free radical scavengers on arachidonic acid metabolism by ovine placental microsomes. Gen. Pharm. 22:1109-1113.

40. Ross, A. F. 1961. Systemic acquired resistance induced by localized virus infections in plants. Virology 14:340-358.

41. Rufty, R. C. 1989. Genetics of host resistance to tobacco blue mold. Pages 141-164 in: Blue Mold of Tobacco. W. E. McKean, ed. American Phytopathological Society, St. Paul, MN.

42. Rufty, R. C., Wernsman, E. A., Main, C. E., and Gooding, G. V., Jr. 1990. Registration of NC-BMR-42 and NC-BMR-90 germplasm lines of tobacco. Crop Sci. 30:241-242.

43. Rustérucci, C., Aviv, D. H., Holt, B. F., III, Dangl, J. L., and Parker, J. E. 2001. The disease resistance signaling components EDS1 and PAD4 are essential regulators of the cell death pathway controlled by LSD1 in Arabidopsis. Plant Cell 13:2211-2224.

44. Schiltz, P. 1981. Downy mildew of tobacco. Pages 577-599 in: The Downy Mildews. D. M. Spencer, ed. Academic Press, London.

45. Shoemaker, P. D. 2004. Disease management. Pages 72-89 in: 2004 Burley Tobacco Information. North Carolina State University, College of Agriculture and life Sciences, Raleigh, NC.

46. Song, J., Braden, J. M., Naess, S. K., Raasch, J. A., Wielgus, S. M., Haberlach, G. T., Liu, J., Kuang, H., Austin-Phillips, S., Buell, C. R., Helgeson, J. P., and Jiang, J. 2003. Gene RB cloned from Solanum bulbocastanum confers broad spectrum resistance to potato late blight. P. Natl. Acad. Sci. USA 100:9128-9133.

47. Soylu, E. M., Soylu, S., and Mansfield, J. W. 2004 Ultrastructural characterization of pathogen development and host responses during compatible and incompatible interactions between Arabidopsis thaliana and Peronospora parasitica. Physiol. Mol. Plant Pathol. 65:67-78.

48. Stevens, N. E., and Ayers, J. C. 1940. The history of tobacco downy mildew in the United States in relation to weather conditions. Phytopathology 30:684-688.

49. Svircev, A., and McKeen, W. E. 1982. The haustorium of Peronospora hyoscyami f. sp. tabacina in the susceptible tobacco leaf cell. Can. J. Plant Pathol. 4:119-128.

50. Tronchet, M., Ranty, B., Marco, Y., and Roby, D. 2001. HSR203J antisense suppression in tobacco accelerates development of hypersensitive cell death. Plant J. 27:115-127.

51. Tyler, B. M., and 52 other authors. 2006. Phytophthora genome sequences uncover evolutionary origins and mechanisms of pathogenesis. 
Science 313:1261-1266

52. Wark, D. C. 1963. Nicotiana species as sources of resistance to blue mold (Peronospora tabacina Adam) for cultivated tobacco. Pages 252-259 in:

Proc. 3rd World Tob. Sci. Cong., Salisbury, Southern Rhodesia. Tobacco Research Board, Harare, Zimbabwe.

53. Wark, D. C. 1970. Development of flue-cured tobacco cultivars resistant to a common strain of blue mold. Tobacco Sci. 14:47-150.

54. Wiglesworth, M. D., Reuveni, M., Nesmith, W. C., Siegel, M. R., Kuc, J., and Juarez, J. 1988. Resistance of Peronospora tabacina to metalaxyl in Texas and Mexico. Plant Dis. 72:964-967.

55. Yu, L. M. 1995. Elicitins from Phytophthora and basic resistance in tobacco. Proc. Natl. Acad. Sci. USA 92:4088-4094. 